Науковий вісник НЛтУ України
Scientific Bulletin of UNFU
http://nv.nltu.edu.ua
https://doi.org/10.15421/40280510
Article received 17.05.2018 p.
Article accepted 31.05.2018 p.
Удк 633.875:630*22/.23:292.486(477)

С. А. Ситник, Л. В. Плотка

Дніпровський держсавний аграрно-економічний університет, м. Дніпро, Україна

\title{
ЩІЛЬНІСТЬ ОСНОВНИХ КОМПОНЕНТІВ ФІТОМАСИ СТОВБУРІВ ДЕРЕВ РОБІНІЇ НЕСПРАВЖНЬОАКАЦІЇ В УМОВАХ ПІВНІЧНОГО СТЕПУ УКРАЇНИ
}

\begin{abstract}
Здійснення лісогосподарських заходів, спрямованих на отримання якісної деревини, раціональне перероблення деревної сировини неможливі без аналізу варіабельності щільності компонентів надземної фітомаси стовбурів - деревини і кори. Наведено результати оцінювання середньої природної та базисної щільності деревини та кори стовбурів робінії несправжньоакації в умовах Північного Степу України. Дослідження проведено на 20 тимчасових пробних площах у робінієвих деревостанах у найпоширеніших групах типів лісу $\left(C_{0}-C_{1}\right)$, віком від 3 до 89 років, продуктивністю ${ }^{\mathrm{A}}-\mathrm{III}$ класів бонітету. Проаналізовано зміну локальної щільності з віком модельних дерев та відносною висотою стовбурів. Середню локальну природну та базисну щільність фракцій фітомаси стовбурів розраховано з використанням комп'ютерної програми PLOT. Встановлено, що показники локальної природної та базисної щільності деревини і кори дерев робінії несправжньоакації в умовах Північного Степу України мають комбінований тип змін із відносною висотою стовбура: від окоренкової частини стовбура до відносної висоти 0,5h відбувається збільшення щільності з подальшим поступовим їі зменшенням від середини стовбура до верхівки дерева. Локальна базисна щільність деревини молодих дерев (3-20 років) має стрімке зростання від окоренкової частини до відносної висоти $0,1 h$ з подальшими змінами, характерними для інших груп віку. Найщільніша деревина і кора в дерев робінії несправжньоакації формується на середині стовбура $(0,5 h)$ у віці $41-60$ років.
\end{abstract}

Ключові слова: Північний Степ; деревостан; локальна природна і базисна щільність; деревина; кора.

Вступ. 3 досліджень розподілу щільності деревини вздовж стовбура можна зрозуміти процес ііі формування на різних етапах росту дерева. Варіації щільності дають змогу отримати попередні відомості про механічні властивості деревини в окремих частинах стовбура (Lakyda, 2002; Vasylyshyn, 2016). У поєднанні з аналізом приросту деревини щільність розглядають як інформативний показник інтенсивності діяльності меристеми в різних зонах стовбурів (Vintoniv, 2007; Szaban et al, 2014; Longuetaud et al, 2016; Sopushynskyy et al, 2016). Наведене вище становить значний теоретичний i прикладний інтерес у практиці ведення лісогосподарської діяльності. Здійснення лісогосподарських заходів, спрямованих на отримання якісної деревини, раціональна переробка деревної сировини мають враховувати закономірності розподілу щільності деревини вздовж стовбура. Високу щільність деревини в дерев пов'язують також із низькими лісогосподарськими затратами на проведення доглядових рубань та зменшенням площі живлення (Larjavaara \& Muller-Landau, 2010).

Особливо актуальними є дослідження якісних показників надземної фітомаси робінії несправжньоакації (Robinia pseudoacacia L.), що формує деревостани у степовій зоні України. Робінія у Північному Степу представлена переважно в лісах захисного функціонального призначення і зростає на площі 16685 га (Sytnyk, 2018).
Мета дослідження - оцінити локальну щільність деревини та кори стовбурів робінії несправжньоакації різного віку в деревостанах Північного Степу України.

Матеріали і методи дослідження. Для дослідження було закладено тимчасові пробні площі за загальноприйнятою лісотаксаційною методикою у робінієвих деревостанах Північного Степу України за попередньо проаналізованими матеріалами лісовпорядкування, у найпоширеніших групах типів лісу $\left(C_{0}-C_{1}\right)$, у деревостанах віком від 3 до 89 років, продуктивністю $\mathrm{I}^{\mathrm{A}}-$ III класів бонітету. Для досягнення мети дослідження оцінювання локальної щільності компонентів фітомаси стовбура дерев робінії - використано методику збирання дослідних даних П. I. Лакиди (Lakyda, 2002),

Польові дослідження проводили в період повної вегетації у червні-вересні. Відбір модельних дерев (МД) на ТПП здійснювали за методом пропорційного ступінчастого представництва з подальшим їх зрубуванням і докладною поліфакторною оцінкою. На ТПП було зрубано й опрацьовано $60 \mathrm{MД} \mathrm{робінії} \mathrm{несправжньоакації}$ (Robinia pseudoacacia L.), зокрема - 20 МД з визначенням щільності деревини та кори стовбура.

3 метою дослідження показників природної (відношення маси зразка до його об'єму у свіжозрубаному стані) та базисної щільності (відношення маси зразка в абсолютно сухому стані до його об'єму у свіжозрубаному

\section{Інформація про авторів:}

Ситник Світлана Анатоліївна, канд. біол. наук, доцент, кафедра садово-паркового господарства. Email: Sytnyk_Svit@ua.fm; https://orcid.org/0000-0002-7646-6347

Плотка Любов Володимирівна, аспірант, кафедра обліку і аудиту. Email: plotkalubov@gmail.com

Цитування за Дсту: Ситник С. А., Плотка Л. В. Щільність основних компонентів фітомаси стовбурів дерев робінії несправжньоакації в умовах Північного степу України. Науковий вісник НлтУ України. 2018, т. 28, № 5. С. 49-52.

Citation APA: Sytnyk, S. A., \& Plotka, L. V. (2018). Wood and bark density of the main components of stem fitomass of the black locust trees within Northern steppe of Ukraine. Scientific Bulletin of UNFU, 28(5), 49-52. https://doi.org/10.15421/40280510 
стані), на пні та відносних висотах модельних дерев $(0,1 h, 0,25 h, 0,5 h, 0,75 h)$ випилювали дослідні зрізи у корі завтовшки 2-3 см. За допомогою спеціальної палетки визначено стереометричні параметри зрізів, а також проведено їхнє зважування у корі та без кори. Після висушування зразків до абсолютно сухого стану у сушильній шафі за температури $+105^{\circ} \mathrm{C}$ знову визначали їхню масу. Об'єми отриманих дослідних зрізів МД, визначені на ПК за допомогою програми ZRIZ, застосували для розрахунку локальної щільності деревини та кори модельних дерев на відносних висотах. Середню локальну

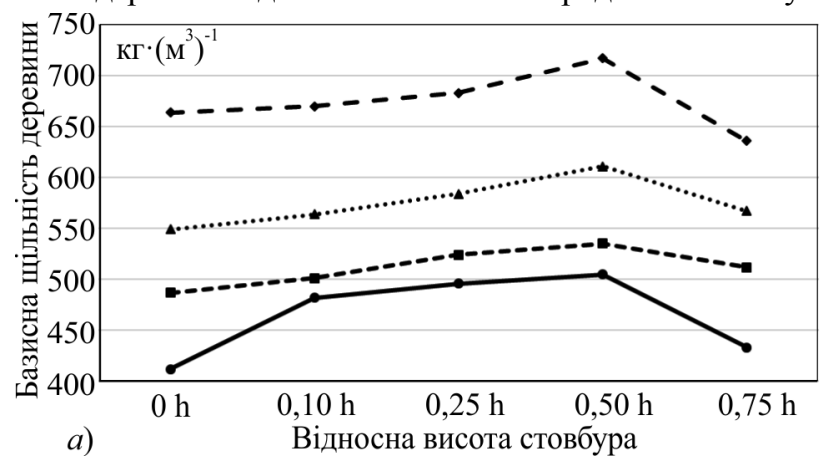
та віком дерев

Базисна локальна щільність деревини робінії має значне варіювання на відносних висотах дерев. У дерев середньовікової (21-40 років) та перестиглої вікової групи (41-60 і 61-80 років) спостерігаємо тенденцію збільшення показників базисної щільності від окоренка до відносної висоти $0,5 h$, де вона досягає максимальних значень 3 подальшим їх зменшенням до верхівки дерева. Тренд базисної локальної щільності деревини для зазначених груп віку є тотожними, але абсолютні значення пошукової характеристики вищі в найстарших дерев 6180 років - 717 кг $/ \mathrm{M}^{3}$. Пошукова характеристика в дерев віком 21-40 років, тобто тих, які досягли віку стиглості в деревостанах Північного Степу України, є більш вирівняною протягом усієї довжини стовбура, але із збереженням тенденції ущільнення деревини до середини стовбура $(0,5 h)$ із подальшим зниженням іiї значень до висоти $0,75 h$. Локальна базисна щільність деревини молодих дерев (3-20 років) має стрімке зростання від окоренкової частини до відносної висоти $0,1 h$ з подальшими змінами, характерними для інших груп віку.

Таку закономірність можна пояснити особливостями формування річних кілець у швидкорослих деревних порід, до яких належить досліджуваний вид (Poluboyarinov, 1976). Завдяки швидкорослості робінії несправжньоакації, одночасно зі збільшенням приросту у висоту, підвищується і приріст за діаметром, що сприяе стабілізації базисної щільності на відносній висоті $0,5 h$.

Тренд показників усередненої природної локальної щільності узгоджується зі змінами базисної локальної щільності деревини стовбурів робініі, тобто їі значення збільшуються від окоренка до середини стовбура, і надалі зменшуються тільки для дерев віком до 40 років, тобто молодняків і середньовікових дерев. Найбільшу за абсолютним значенням пошукову характеристику зафіксовано у дерев віком 41-60 років на відносній висоті стовбура $0,5 h$.

За даними графічного зображення усередненої природної локальної щільності деревини робінії несправжньоакації можна спостерігати різноспрямовані тенденції зміни цієї якісної характеристики надземної природну та базисну щільність фракцій фітомаси стовбурів модельних дерев (деревини, кори), розрахували 3 використанням комп'ютерної програми PLOT.

Результати дослідження. Локальна щільність структурних компонентів фітомаси стовбурів модельних дерев робінії демонструє особливості формування деревини та кори в різних його частинах.

Зміну усередненої локальної базисної та природної щільності деревини стовбурів робінії несправжньоакації відображають криві, які представлять чотири групи віку (рис. $1 ; a, \sigma)$.

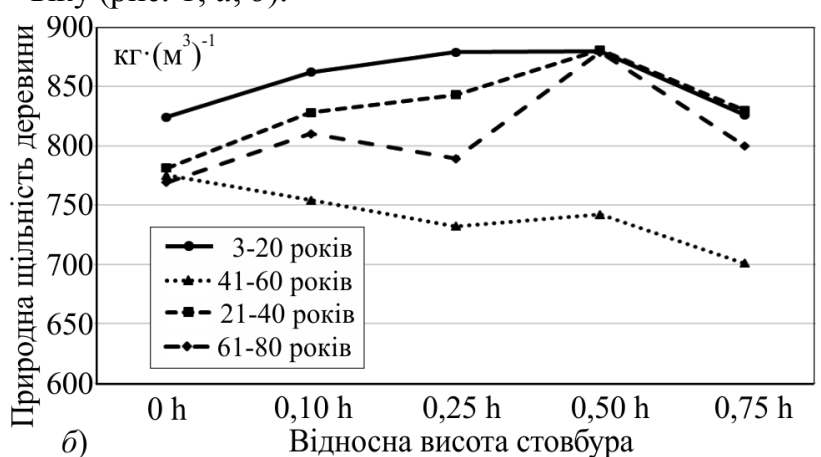

б) Відносна висота стовбура

фітомаси у перестиглих дерев. У дерев віком 40-60 років наявний низхідний тип: від окоренкової частини до верхівки дерева природна локальна щільність зменшується.

Дослідженням щільності кори надають меншої уваги, хоча кора в робінії несправжньоакації, що формує деревостани у Північному Степу України, становить значну частину від об'єму стовбура - 25,8 \%, порівняно 3 іншими породами, ясен звичайний - 13-28 \% (2016), осика - 12,6 \%, (Lakyda \& Mateyko, 2010). Динаміку середніх показників локальної базисної та природної щільності кори стовбурів робінії можна оцінити на рис. 2 ; а, б.

Порівняно зі щільністю деревини, щільності кори на відносних висотах стовбура за віковими діапазонами притаманна значніша мінливість. Варіабельність локальної базисної щільності кори значно менша, ніж у природної як за групами віку, так і за відносними висотами (див. рис. 2; $a$, б).

Загальною закономірністю зміни базисної та природної локальної щільності кори для всіх груп віку дерев робінії є збільшення їхніх значень від окоренкової частини до середини стовбура (відносна висота 0,5 h) 3 різним ступенем рівномірності: до середини стовбура характеризується висхідним типом, а на верхній половині стовбура - низхідним (Poluboyarinov, 1976).

За умови збереження загального тренду, для дерев різного віку зміна значень базисної локальної щільності $\epsilon$ неоднаковою. Найбільші абсолютні значення базисної локальної щільності кори характерні для наймолодших

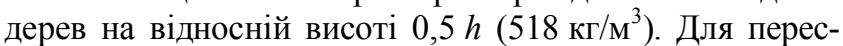
тиглих дерев зазначена тенденція зберігається, але абсолютні значення $є$ значно меншими. Для дерев віком понад 60 років загалом характерним $є$ висхідний тип зміни базисної локальної щільності кори 3 незначним спадом на половині висоти стовбура, проте, на відміну від дерев інших вікових груп, зниження значень пошукової якісної характеристики починається 3 відносної висоти $0,25 h$. 

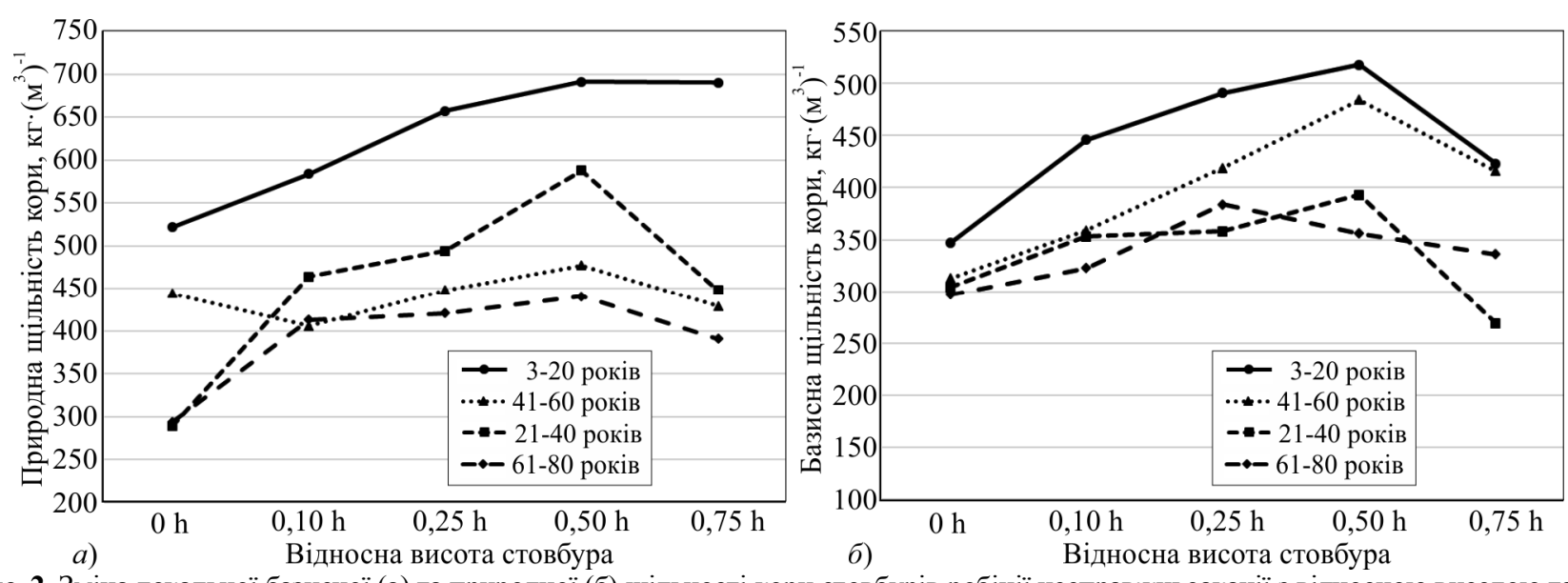

Рис. 2. Зміна локальної базисної (а) та природної (б) щільності кори стовбурів робінії несправжньоакації з відносною висотою та віком дерев

На відміну від базисної локальної щільності деревини, яка для дерев усіх груп віку має висхідний тип, характер зміни локальної природної щільності кори робінії неоднотипний для дерев різного віку. Для дерев віку 61-80 років на стовбурі від окоренка до відносної висоти $0,1 h$ спостерігаємо дуже різке збільшення щільності кори, від $0,1 h$ до $0,25 h$ залишається майже незмінною, надалі до відносної висоти 0,5 повільно зростає, і до верхівки поступово зменшується.

Характер зміни природної локальної щільності кори для молодняків та середньовікових насаджень практично однаковий - збільшення від окоренкової частини до відносної висоти 0,5 h 3 подальшим поступовим і рівномірним зменшенням до верхівки.

Висновки. Встановлено, що розраховані середні показники локальної природної та базисної щільності деревини і кори дерев робінії несправжньоакації в умовах Північного Степу України мають комбінований тип змін із відносною висотою: від окоренкової частини стовбура до відносної висоти $0,5 h$ відбувається збільшення щільності з подальшим поступовим іiі зменшенням від середини стовбура до верхівки. Найбільш щільна деревина i кора в робінії несправжньоакації формується на середині стовбура $(0,5 h)$ у віці $41-60$ років.

Одержані дані про локальну базисну і природну щільність та їх варіабельність за відносними висотами і віковими діапазонами модельних дерев дають можливість якісно охарактеризувати компоненти фітомаси окремих частин стовбурів дерев робінії, а також будуть як базис для розрахунку усереднених показників щільності компонентів фітомаси стовбурів дерев робінії.

\section{Перелік використаних джерел}

Lakyda, P. I. (2002). Fitomasa lisiv Ukrainy. Ternopil: Zbruch. 256 p. [In Ukrainian].

Lakyda, P. I., \& Mateiko, I. M. (2016). Fitomasa ta deponovanyi vuhlets derev $i$ derevostaniv yasena zvychainoho u Pravoberezhnomu Lisostepu Ukrainy. Kyiv: Komprynt. 156 p. [In Ukrainian].

Larjavaara, M., \& Muller-Landau, H. C. (2010). Rethinking the value of high wood density. Functional Ecology, 24, 701-705. https://doi.org/10.1111/j.1365-2435.2010.01698

Longuetaud, F., Mothe, F., Fournier, M., Dlouha, Ja., Santenoise, Ph., \& Deleuze, Ch. (2016). Within-stem maps of wood density and water content for characterization of species: a case study on three hardwood and two softwood species. Annals of Forest Science, 73, 601-614. https://doi.org/10.1007/s13595-016-0555-4

Poluboiarinov, O. I. (1976). Plotnost drevesiny. Moscow: Lesn. promst. 160 p. [In Russian].

Sopushynskyy, I., Kharyton, I., Teischinger, A., Mayevskyy, V., \& Hrynyk, H. (2016). Wood density and annual growth variability of Picea abies (L.) Karst. growing in the Ukrainian Carpathians. Eur. J. Wood Prod., 75(3), 419-428. https://doi.org/10.1007/s00107016-1079-1

Sytnyk, S. A. (2018). The modeling of black locust crown morphometric indicators in the northern steppe of ukraine. Scientific $\begin{array}{llll}\text { Bulletin of } & \text { 28(1), } & \text { 34FU, }\end{array}$ https://doi.org/10.15421/40280106

Szaban, J., Kowalkowski, W., Karaszewski, Z., \& Jakubowski, M. (2014). Effect of tree provenance on basic wood density of Norway spruce (Picea abies [L.] Karst.) grown on an experimental plot at Siemianice Forest Experimental Station. Drewno, 57(191), 135-144. https://doi.org/10.12841/wood.1644-3985.061.10

Vasylyshyn, R. D. (2016). Lisy Ukrainskykh Karpat: osoblyvosti rostu, biolohichna ta enerhetychna produktyvnist. Kyiv: Komprynt, 418 p. [In Ukrainian].

Vintoniv, I. S., Sopushynskyy, I. M., \& Teischinger, A. (2007). Wood Science. Lviv: Apriori, 360 p. [In Ukrainian].

С. А. Сытник, Л. В. Плотка Днепровский государственный аграрно-экономический университет, г. Днепр, Украина

\section{ПЛОТНОСТЬ ОСНОВНЫХ КОМПОНЕНТОВ ФИТОМАССЫ СТВОЛОВ ДЕРЕВЬЕВ РОБИНИИ ЛОЖНОАКАЦИИ В УСЛОВИЯХ СЕВЕРНОЙ СТЕПИ УКРАИНЫ}

Осуществление лесохозяйственных мероприятий, направленных на получение качественной древесины, рациональная переработка древесного сырья невозможна без анализа вариабельности плотности компонентов надземной фитомассы стволов - древесины и коры. Приведены результаты оценки средней природной и базисной плотности древесины и коры стволов робинии ложноакации в условиях Северной Степи Украины. Исследование проведено на 20 временных пробных площадях в робиниевых древостоях в наиболее распространенных группах типов леса $\left(C_{0}-C_{1}\right)$, возрастом от 3 до 89 лет, продуктивностью IA -III классов бонитета. Проанализировано изменение локальной плотности с возрастом модельных деревьев и относительной высотой стволов. Средняя локальная природная и базисная плотность фракций фитомассы стволов рассчитана с использованием компьютерной программы PLOT. Установлено, что показатели локальной природной и базисной плотности древесины и коры деревьев робинии ложноакации в условиях Северной Степи Украины имеют комбинированный тип изменений с относительной высотой ствола. От комлевой части ствола до относительной высоты $0,5 h$ происходит увеличе- 
ние значений плотности с последующим постепенным их уменьшением от середины ствола к вершине дерева. Локальная базисная плотность древесины молодых деревьев (3-20 лет) имеет стремительное увеличение от комлевой части к относительной высоте $0,1 h$ с последующими изменениями, характерными для других возрастных групп. Наиболее плотная древесина и кора у деревьев робинии ложноакации формируется на середине ствола $(0,5 h)$ в возрасте $41-60$ лет.

Ключевые слова: Северная Степь Украины; древостои; локальная природная и базисная плотность; древесина; кора.

S. A. Sytnyk, L. V. Plotka WOOD AND BARK DENSITY OF THE MAIN COMPONENTS OF STEM FITOMASS
OF THE BLACK LOCUST TREES WITHIN NORTHERN STEPPE OF UKRAINE

Implementation of forestry measures aimed at obtaining high-quality wood, rational processing of wood raw materials is impossible without analyzing the variability of the density of the components of the trunk aboveground phytomass such as wood and bark. The results of estimation of the average natural and basic density of wood and bark of the stem of black locust trees under conditions of the northern steppe of Ukraine are presented. The object of the survey was Black locust (Robinia pseudoacacia L.) plantation of the Ukrainian Steppe zone. The experimental data of model tree from temporary plots were analyzed. The study was conducted on the 20 temporary plots in black locust stands in the most forest types, aged 3 to 89 years old, and productivity of $\mathrm{I}^{\mathrm{A}}$-III classes of the bonitat. Thirty model trees of Black locust were selected on the sample plots with an area of 0.25 ha each, established in forest stands of different age. The variation of local nature and basic wood and bark density with the age of model trees and relative height of trunks were analyzed. The average local natural and basic density of the fractions of trunk phytomass was calculated using the computer program PLOT. It is revealed that the indices of the local natural and basic density of wood and bark of black locust trees in the conditions of the Northern Steppe of Ukraine have a combined type of changes with relative height of the trunk. From the compartment part of the trunk up to a relative height of $0.5 h$, an increase in the density values occurs, with subsequent gradual decrease from the middle of the trunk to the top of the tree. The local basic density of wood of young trees (320 years old) has a rapid increase from the compartment part to a relative height of $0.1 \mathrm{~h}$ with subsequent changes characteristic of other age groups. The most wood and bark natural density in the black locust trees were formed on the middle of the trunk $(0.5 \mathrm{~h})$ at the age of 41-60 years. The obtained data on the local basic and natural density and their variability by relative heights and age ranges of model trees give an opportunity to characterize qualitatively the components of the phytomass of individual parts of the trunks of black locust trees.

Keywords: Northern Steppe of Ukraine; forest stands; local natural and basic density; wood; bark. 